\title{
Seabirds in the Bay of Bengal large marine ecosystem: Current knowledge and research objectives
}

\author{
Ravichandra Mondreti ${ }^{1,2^{\star}}$, Priya Davidar $^{2}$, Clara Péron $^{1}$, David Grémillet ${ }^{1,3}$ \\ ${ }^{1}$ Equipe Ecologie Spatiale des Populations, CEFE-CNRS UMR 5175, Centre d'Ecologie Fonctionnelle et Evolutive, Montpellier, \\ France; ${ }^{*}$ Corresponding Author: ravichandra.mondreti@ece.cnrs.fr \\ ${ }^{2}$ Department of Ecology and Environmental sciences, Pondicherry University, Kalapet, India \\ ${ }^{3}$ Percy FitzPatrick Institute of African Ornithology, NRF-DST Centre of Excellence at the University of Cape Town, Rondebosch, \\ South Africa
}

Received 12 December 2012; revised 24 January 2013; accepted 13 February 2013

Copyright (C) 2013 Ravichandra Mondreti et al. This is an open access article distributed under the Creative Commons Attribution License, which permits unrestricted use, distribution, and reproduction in any medium, provided the original work is properly cited.

\section{ABSTRACT}

Seabirds are good candidates as ecological indicators, especially in under-studied ecosystems since they provide insights into marine ecosystem processes and functions at various trophic levels. Our review discusses salient points on the present status of seabirds in the Bay of Bengal Large Marine Ecosystem; despite overall low seabird numbers and biomass, this region harbors 9 species of terns, one of the most threatened bird group worldwide, which are known to breed in various marine habitats of Andaman and Nicobar islands, in addition to the coastal areas of mainland. Further, we elaborate on employing seabirds as potential indicators of this ecosystem and how they outscore other taxa in this aspect. Finally, we argue that it is essentially to fill the gaps in our knowledge about the BOBLME, mainly about the interplay between seabirds, climate change and fisheries.

Keywords: Biomass; Climate Change; Ecological Indicators; Marine Pollution; Primary Productivity; Pelagic; Trophic Level

\section{INTRODUCTION}

Among the 64 large marine ecosystems of the world, BOBLME encompasses the following countries, Maldives, Srilanka, India, Bangladesh, Myanmar, Thailand, Malaysia and Indonesia under its jurisdiction. The LME covers an area of about $3,657,502 \mathrm{~km}^{2}$, of which $0.49 \%$ is protected [1] and includes the entire East coast which is nearly $50 \%$ of India's coastline. Merely $2 \%$ of the total coastal area of Bay of Bengal is officially designated as Marine Protected Areas (MPAs) [2] and according to [3], there are 31 MPAs in India, with an areal extent of about 627,121 ha, a mere $0.002 \%$ of the entire land mass of India. There are no notified Pelagic Protected Areas (PPAs) in the Bay of Bengal and for that matter, none in the marine waters of India.

The BOBLME limits in India extend from the northern coastal state of West Bengal to the southern-most point, Kannyakumari in Tamil Nadu [4]. Coastal states, territories and regions of significance bordering the LME include West Bengal, Orissa, Andhra Pradesh, Tamil Nadu, Puducherry (Pondicherry), and the Andaman and Nicobar Islands.

Major rivers like the Ganges, Brahmaputra, Mahanadi, Godavari, Krishna and Cauvery discharge millions of litres of water per day into the Bay of Bengal, mostly mixed with human sewage and effluents from the industries along the coastline. Human population living directly along the coast of the BOBLME area exceeds 225 million in total, and there are six major and five minor ports along the coast [5].

More than 400 million people in the BOBLME region depend directly or indirectly upon this 6.2 million $\mathrm{km}^{2}$ fragile marine ecosystem for their food as well as livelihood. Imprudent use of this LME, should be checked to meet the needs of both the current as well as of future generations [2].

The BOBLME is, overall, a class I, highly productive ecosystem $\left[>300 \mathrm{~g}\right.$ carbon $/ \mathrm{m}^{2} /$ year] $([1,6])$, yet the central part of the bay is less productive because of the absence of large-scale mixing or upwelling on the contrary to coastal waters which receive large amounts of nutri- 
ents from river runoff causing sudden phytoplankton bloom [7]. The primary productivity in the BOBLME ranges from a minimum of $385 \mathrm{~g} \mathrm{C} \mathrm{m}^{-2} \cdot$ year $^{-1}$ in the Maldives to a maximum of $1700 \mathrm{~g} \mathrm{C} \mathrm{m}^{-2} \cdot$ year $^{-1}$ in Bangladesh, with an average of $730 \mathrm{~g} \mathrm{C} \mathrm{m}^{-2} \cdot \mathrm{year}^{-1}$ [1]. Such productivity is twice that of the North Sea, or of the Benguela Large Marine Ecosystems, even though upwelling is limited only to the continental shelf of the Bay of Bengal [5]. The average Chlorophyll "a" concentration is $0.52 \mathrm{mg} \cdot \mathrm{m}^{-3}$ [6], which also indicates its productivity.

Significant spatial and temporal variability have been detected all along the BOBLME coastline because of high seasonal river discharges [8]. Periodic monsoon discharges lead to the formation of 100 - $150 \mathrm{~m}$ layer characterized by low salinity and high oxygen content [9], triggering high primary productivity in certain parts of the BOBLME. This condition persists perennially especially in the northern Bay, owing to the GangesBrahmaputra river discharge [4].

Marine research conducted in the BOBLME so far largely focused on physical oceanography $([8,10])$ and fisheries science $([11,12])$, with hardly any emphasis on marine top predators beyond fish including marine mammals. In particular, there is currently no synthesis on the ecological perspective of seabirds in BOBLME. Our review aims at filling this gap, and at identifying forthcoming research objectives.

\section{WHY STUDY SEABIRDS}

\subsection{Seabirds Provide Insights into Oceanic Ecosystems}

Seabirds are suitable candidates for signaling changes in the oceanic environment at various scales. They possess unique characteristics such as easy detectability and identification, and breed on land while depending on the marine environment for food [13]. Additionally, they have long life spans [14] when compared to other marine species, making them a convenient indicator taxon to monitor changes and trends over long periods of time at various trophic levels [15]. Seabirds are one among a series of top predators in a marine ecosystem, sharing or competing for prey with marine mammals or predatory fish, yet their breeding populations on land are far more convenient for monitoring than those of any other marine vertebrates. Small pelagic fish are known to regulate the seabird populations ([16-18]) and may therefore signal environmental induced fluctuations in prey availability. $([19,20])$.

\subsection{SEABIRDS AND CLIMATE CHANGE}

Declines in seabird abundance have been demon- strated in the California current, and linked to rising sea surface temperatures $([21,22])$. At a larger scale, periodic events such as El Nino have a profound impact on the seabird populations [23] due to declines in marine productivity [24]. These periodic phenomena have adverse effects on seabird breeding cycles over successive years, due to rising sea surface temperatures (SST's). Their recurrence due to anthropogenic warming of the world's oceans $([25,26])$ may lead to the extinction of many seabird species.

Over the years seabird data have been useful to study the structural and functional changes in marine ecosystems. Elsewhere, the seabird community of the North sea changed in structure and composition [27], with changes at lower trophic levels (plankton) affecting higher trophic levels, and vice versa [28]. Such intricate mechanisms in the marine food chain, which depend on ecosystem structure and function, have yet to be understood in most Large Marine ecosystems across the world. One important variable in this context is seabird diet, and dietary plasticity [29]. For example, significant diet switches and variable reproductive output of 11 species of seabirds in the California Current indicate low frequency climate changes [30]. A careful study of seabird diets across various marine systems therefore provides information about prominent climatic changes happening at many time scales (seasonal, annual and multi-annual) [31]. A thorough understanding of how seabird communities respond to climate change is therefore essential, yet these communities are equally challenged by other human activities, such as fisheries or pollution [24].

\subsection{Seabirds as Indicators Most Useful in Under-Studied Ecosystems}

Less developed areas are under constant threat of developmental pressures, mainly due to exploitative fishing [32]. In such scenario, ecosystem-based management practices may work too slowly to prevent rapid, unsustainable harvesting of marine resources [29]. For the above reason, the Convention on the Conservation of Antarctic Marine Living Resources (CCAMLR), has emphasized on following sentinel species approaches [33] rather than an ecosystem-based approach [34]. The above statement strongly underlines the potential of seabirds for truly representing a marine ecosystem as indicator species from an ecological and economical perspective, and more so in a management context [33].

Pollution of the marine habitats in the developed as well as developing countries is of prime concern due to dumping of wastes at an alarming rate. Many studies in the past have confirmed the use of seabirds as model species in studying levels of pollution in the marine environment (e.g [15,35-37]). As seabirds are truly trans- 
boundary in nature, not restricted by political frontiers [13] their migratory behavior makes them an interesting group of species for studying bioaccumulation and biomagnification of pollutants at various trophic levels in the oceanic systems.

\section{SUMMARIZING INFORMATION AND IDENTIFYING GAPS IN KNOWLEDGE}

Most marine related studies in the BOBLME are confined to physical oceanography and fisheries science, leaving important gaps in our understanding of the marine communities. Most studies on seabirds in the Indian subcontinent are based on opportunistic records rather than systematic, dedicated censuses.

\subsection{Species Diversity, Population Sizes and Distribution}

\subsubsection{Breeding Population}

From Table 1 it is evident that the exact number of the seabirds breeding in each BOBLME colony is unknown.

Most of the tern species i.e. 9 among 11 are known to breed in the Indian sub-continent, and this is therefore the major seabird group to be expected in the BOBLME. However, as for other species, there are no specific population estimates for any of these tern species within our study area, except isolated records of breeding colonies of (Onychoprion fuscata) Sooty Terns within the Bay of Bengal proper, and confirmed records of breeding on the west coast of India, especially in Lakshadweep ([38,39]). Overall, breeding numbers mentioned in Table $\mathbf{1}$ are likely under-estimates due to lack of extensive and continuous monitoring.

\subsubsection{Non-Breeding Population}

Most species records are either single doubtful sightings or museum specimens collected by anonymous persons. Complete population count details are given only in the case of Asian water bird census reports (1987-2007) and that too only for few species of gulls and terns, and for a very limited number of sites. Moreover, most information on species records is outdated, except those from the Asian water bird census. Clearly, this demonstrates the need for thorough census of the non breeding population, through at-sea surveys, in addition to breeding censuses.

\subsection{GAPS IN KNOWLEDGE AND OBJECTIVES}

\subsubsection{Breeding Seabird Biogeography in the Bob}

Seabirds, due to their colonial nesting habits, may breed in relatively small areas in densely packed colonies.
This comes to their disadvantage especially in the case of tropical seabird colonies where they are subjected to a variety of anthropogenic threats in the form of poaching of eggs ([40,41]), guano collection, invasive predators [42]. In the BOBLME, many of the seabird colonies have not been assigned legal protection status even though most of them fall under the Marine Protected Areas' (MPA's) jurisdiction.

There is no complete information on the exact location and position and number of breeding colonies. Even when breeding colonies have been identified during accidental sightings, most of the site locations have yet to be confirmed by a census. Seabird colonies are poorly known around the mainland coast except the terns nesting on Vengurla Rocks off the west coast and on some of the islets in Adam's Bridge [43]. Very few species breed in the Lakshadweep and Andaman and Nicobar islands [44]. In Lakshadweep, (Anous stolidus) Brown Noddy, (Sterna fuscata) Sooty Tern, and possibly (Pufinus lherminieri) Audubon's Shearwater, (Sula dactylatra) Masked Booby, (Sula sula) Red-footed Booby and (Sula leucogaster) Brown Booby; there are also important colonies on Pitti and Baliapani [45]. In the Andamans, (Sterna dougalli) Roseate Tern, (Sterna sumatrana) Black-naped Tern, and probably (Sterna fuscata) Sooty Tern; In Nicobars, (Sterna sumatrana) Black-naped Tern and (Anous stolidus) Brown Noddy. Some of the information about breeding seabird species are based on very few or single records which have yet to be confirmed. Moreover, most of the information on the status of the breeding colonies is outdated and there is a real necessity for detailed breeding surveys. Information about the location and status of the seabird breeding colonies will be very helpful for the government in making policy changes and in assigning legal protection status to some of the pelagic seabird rich areas in the LME, which are otherwise left unprotected.

\subsubsection{Seabird At-Sea Distributions and Community Composition in the BoB}

At-sea data provide a thorough understanding about the species biology including their distribution, composition at both community and population levels, interspecific interactions (prey-predator) and oceanographic parameters such as salinity, temperature, bathymetry and if possible of fish taken by the birds [13]. Species-habitat relationships provide information about distribution and migratory patterns on a seasonal basis. At-sea survey may also provide information about other marine predators like whales, seals and predatory fish, on which seabirds may depend for locating their prey (small pelagic fish). Additionally, seabird behavioral data can be gathered during sea surveys which are essential for understanding marine community structure and interactions. 
There is hardly any information available on seabirds at sea in the BOBLME, and therefore collecting such data is a major goal for future work. In the past, very few at-sea surveys have been carried out in this LME. There are only few records of seabird sightings during cruises by amateur birdwatchers.

\subsubsection{Seabirds as Indicators of Pollutant Levels in the BoB}

Seabirds act as indicator species for evaluating the state of aquatic ecosystems [46] due to their bioaccumulation of pollutants and contaminants in quantity with age [47]. Moreover they utilize diverse and broad geographic areas at various trophic levels $([35,48])$, reaffirming their status as good indicator taxon. Seabirds can therefore be cost-efficient environmental samplers.

Past studies have primarily focused on investigating the presence of pollutants in marine areas using seabirds and marine mammals as model species (e.g. [35-37]). However, most such studies in the BOBLME are restricted to the lower taxa, namely mussels [49], and relatively few species of commercially important pelagic fish [12]. The pollutants detected are known to cause serious damage to tissues and organs in some of the taxa like (Macrobrachium sp.,) shrimps and fishes, (Catla catla and Labeo rohita). Elsewhere, high levels of pollutants have been known to occur in seabird tissues including eggs and hatchlings. For instance, high concentrations of toxic heavy metals like Mercury, Cadmium and Arsenic have been reported in the eggs of (Larus marinus) Great black-backed gulls, (Sterna hirundo) common terns and (Sterna forsterii) Forster's terns in Barnegat bay, New Jersey, USA [50]. Of the three components, Mercury is known to persist for a very long time in marine food webs due to extensive bio-amplification and in seabirds these concentrations are known to occur in high concentrations, especially in the muscles and feathers. Further, Polychlorinated biphenyls (PCBs) and organochlorine pesticides are observed in unhatched penguin eggs in Antarctica [51], owing to migration of these chemicals over long distances.

In the case of BOBLME, there is a paucity of information on the concentration and effects of toxic heavy metals and POPs (Persistent Organic Pollutants), on upper trophic marine organisms. Indeed, no accurate information is available in the literature on the volume and amount of these pollutants discharged into the coastal waters of BOBLME through various land based sources such as metallurgy industries and sewage effluents. A thorough literature review has confirmed the need for such studies on seabirds to be carried out in future, considering their position in the marine food web, which would reveal the biomagnifying effects of these pollutants in the marine environment.
Indeed, both the southern Bay of Bengal and the Gulf of Mannar region form a part of one of the two major tanker routes [52]. 96 major factories in Nabadwip discharge almost half a billion litres of untreated wastes per day [53] and perhaps the figure will have doubled or tripled by now. Above all is the grave problem of huge population expansion in India, which will have an adverse impact on marine ecosystems in the coming years due to dumping of wastes especially sewage and human wastes [54], a major contaminant reported in the coastal waters of the LME at regular frequencies. Only scanty information was available on the type of pollutants and their pathways in marine ecosystems.

\subsubsection{Seabird/Fishery Interactions in the BoB}

Nearly 75\% (i.e., 83 million tonnes) of total catches in the BOBLME during 1950-2006 accounted for only five taxa/species, namely herring-like fish (Clupeiformes, 71,000 t.year $^{-1}$ since 2000), Indo-pacific mackerel (Rastrelliger spp., 125,000 t.year ${ }^{-1}$ since 2000), Hilsa shad (Tenualosa ilisha, 168,000 t·year ${ }^{-1}$ since 2000), skipjack tuna (Katsuwonus pelamis, 143,000 t:year ${ }^{-1}$ since 2000) and 'drums or croakers' (Sciaenidae, 100,000 t'year ${ }^{-1}$ since 2000) [2]. The vast majority of total catch comes from relatively shallow, near shore coastal waters.

The region is currently experiencing immense fishing pressure, which is a key factor in the biomass changes in the LME [55] and more evidently visible in the recent declines in the size and weight of key species. The 400 million people, who live along the Bay of Bengal coastline, depend solely or partially on fishing [56]. Tropical seabirds which move across vast areas of the ocean [57] also forage for non-commercial fish species, mainly sub pelagic in nature, but also be caught accidentally by fisheries, and depleted [28].

Offshore species like the skipjack tuna are of prime significance in tropical waters due to their association with procellariformes for feeding opportunities $([13,58])$ and also many seabirds being near obligate commensals of tuna. Extensive tuna fishing in recent years is therefore assumed to have an adverse impact on seabird populations. Our current understanding about the relationships between tunas and seabirds is negligible with respect to the BOBLME. Paradoxically, tuna management has not received any great deal of attention during management decisions [13].

Larger-scale threats to marine resources in the Gulf of Mannar include indiscriminate trawling, dynamite fishing, and the harvesting of specific species like ornamental fish, invertebrates and endangered dugongs and turtles [5]. There are many incidences of seabirds as a bycatch in fishing nets due to destructive and harmful fishing practices such as longline fishing, which are underreported in the BOBLME. Quantification of such de- 
structive fishing practices is therefore essential in this LME, as it will provide us information on how much marine biomass is extracted and which species are being most affected due to illegal fishing.

Lastly, studies on the diet of seabirds can reveal intricacies in the marine food webs [59] which are otherwise difficult to measure using conventional sampling methods.

\section{SUMMARY OF THE MAIN RESEARCH OBJECTIVES FOR A BETTER UNDERSTANDING OF SEABIRD ECOLOGY IN THE BOBLME}

1) Perform a complete breeding census as well as at-sea observations so as to gain community-level understanding of seabird biogeography in the BoBLME. Importantly, this will allow testing the hypotheses that the pelagic seabird community in $\mathrm{BOB}$ is more diverse than the breeding seabird community due to visiting/migratory species (shearwaters and petrels), and that the pelagic seabird community is richer in the Northern part of BOB because of a productivity gradient.

2) Record baseline and spatio-temporal patterns of contaminants in seabirds breeding within the BoBLME. This will allow testing their potential forthcoming use as bio-samplers of a series of pollutants, and testing the hypotheses that seabird contamination is higher in the Northern portion of BOB because of major river runoff.

3) Perform at-sea observations to test the hypothesis that tropical seabirds such as terns from the BoBLME critically depend upon pelagic fish and/or marine mammals to access small pelagic fish.

\section{ACKNOWLEDGEMENTS}

Our synthesis work was funded by a MAHEVA fellowship of the University Montpellier II to Ravichandra Mondreti, and by the Centre d'Ecologie Fonctionnelle et Evolutive, CNRS Montpellier. We are grateful to Fabien Vaugarny, Project Manager, MAHEVA, University of Montpellier 2, Montpellier, France for assisting in prompt disposal of funding money to Ravichandra Mondreti.

\section{REFERENCES}

[1] Chou SAUP (2011) Sea around us project. www.seaaroundus.org

[2] BOBLME (2011) Status of marine protected areas and fish refugia in the Bay of Bengal large marine ecosystem. http://www.boblme.org/documentRepository/BOBLME-2 011-Ecology-10.pdf

[3] Singh, H.S. (2003) Marine protected areas in India. Indian Journal of Marine Sciences, 32, 226-233.

[4] DRAFT BOBLME Transboundary diagnostic analysis-Volume 2: Background and environmental assess- ment (2010) Bay of Bengal large marine ecosystem project.

http://www.boblme.org/documentRepository/BOBLME\% 20draft $\% 20$ TDA $\% 20$ vol1\%20for $\% 20$ national $\% 20$ consult ations.pdf

[5] Sampath, V. (2003) India: National report on the status and development potential of the coastal and marine environment of the east coast of India and its living resources. GEF/FAO Bay of Bengal Large Marine Ecosystem Programme, 296.

[6] Sherman, K and Hempel, G. (2009) The UNEP large marine ecosystem report: A perspective on the changing conditions of the LMEs of the world's regional seas. UNEP Regional Seas Report and Studies, United Nations Environment Programme, Nairobi, Kenya.

[7] Dwivedi, S. N. (1993) Long-term variability in the food chain, biomass yield and oceanography of the Bay of Bengal ecosystem. In: Sherman, K., Alexander, L. M. and Gold, B. D., Eds., Large Marine Ecosystems: Stress, Mitigation, and Sustainability, AAAS Press, Washington DC, 43-52.

[8] Prasanna Kumar, S., Narvekar, J., Nuncio, M., Kumar, A., Ramaiah, N., Sardesai, S., Gauns., M., Fernandes, V. and Paul, J. (2010) Is the biological productivity in the Bay of Bengal light limited? Current science, 98, 13311339.

[9] Dwivedi, S.N and Choubey, A.K. (1998) Indian Ocean large marine ecosystems: Need for national and regional framework for conservation and sustainable development. In: Sherman, K. Okemwa E. and Ntiba M., Eds., Large Marine Ecosystems of the Indian Ocean: Assessment, Sustainability, and Management, Blackwell Science, Cambridge, 327-333.

[10] Satpathy, K. K., Mohanty, A. K., Sahu, G., Sarguru, S., Sarkar, S. K. and Natesan, U. (2011) Spatio-temporal variation in physicochemical properties of coastal waters off Kalpakkam, southeast coast of India, during summer, pre-monsoon and post-monsoon period. Environmental Monitoring Assessment, 180, 41-62. doi:10.1007/s10661-010-1771-2

[11] Das, B., Khan, Y. S. A., Das, P. and Shaheen, S.M. (2002) Organochlorine pesticide residues in catfish, Tachysurus thalassinus (Ruppell, 1835), from the South Patches of the Bay of Bengal. Environmental Pollution, 120, 255259. doi:10.1016/S0269-7491(02)00153-7

[12] Lakshmanan, R., Kesavan, K., Vijayanand, P., Rajaram, V. and Rajagopal, S. (2009) Heavy Metals accumulation in five commercially important fishes of Parangipettai, southeast coast of India. Advance Journal of Food Science and Technology, 1, 63-65.

[13] Ballance, L.T. (2007) Understanding seabirds at sea: Why and how? Marine Ornithology, 35, 127-135.

[14] Parsons, M., Mitchell, I., Butler, A., Ratcliffe, N., Frederiksen, M., Foster, S. and Reid, J.B. (2008) Seabirds as indicators of the marine environment. ICES Journal of Marine Science, 65, 1520-1526. doi:10.1093/icesjms/fsn155

[15] Piatt, J.F., Sydeman, W. J. And Wiese, F. (2007) Introduction: A modern role for seabirds as indicators. Marine 
Ecology progress series, 352, 199-204. doi:10.3354/meps07070

[16] Birkhead, T.R. and Furness, R.W. (1985) Regulation of seabird populations. In: Sibly, R.M. and Smith, R.H., Eds., Behavioural Ecology, Blackwell, Oxford, 145-167.

[17] Hunt, G.L., Eppley, Z.A. and Schneider, D.C. (1986) Reproductive performance of seabirds: The importance of population and colony size. The Auk, 103, 306-317.

[18] Hunt, G.L., Piatt, J.F. and Erikstadt, K.E. (1990) How do foraging seabirds sample their environment? Acta XX Congressus Internationalis Ornithologici, Christchurch, 2272-2280.

[19] Durant, J.M., Hjermann, D.Ø., Frederiksen, M., Charraissin, J.B., et al. (2009) Pros and cons of using seabirds as ecological indicators. Climate Research, 39, 115-129. doi: $10.3354 / \mathrm{cr} 00798$

[20] Cury, P. M., et al. (2011) Global seabird response to forage fish depletion-One-third for the birds. Science, 334, 1703-1706. doi:10.1126/science. 1212928

[21] Veit, R.R., Pyle, P. and McGowan, J.A. (1996) Ocean warming and long-term change in pelagic bird abundance within the California current system. Marine Ecology Progress Series, 139, 11-18. doi:10.3354/meps139011

[22] Hyrenbach, K.D. and Veit, R.R. (2003) Ocean warming and seabird communities of the southern California Current System (1987-1998): Response at multiple temporal scales. Deep Sea Research Part II: Topical Studies in Oceanography, 50, 2537-2565. doi:10.1016/S0967-0645(03)00123-1

[23] Murphy, R.C. (1936) The oceanic birds of South America. American Museum of Natural History. Macmillan, New York.

[24] Gremillet, D. and Boulinier, T. (2009) Spatial ecology and conservation of seabirds facing global climate change a review. Marine Ecology Progress Series, 391, 121-137. doi: $10.3354 /$ meps 08212

[25] Levitus, S., Antonov, J.I., Boyer, T.P. and Stephens, C. (2000) Warming of the world ocean. Science, 287, 22252229. doi:10.1126/science.287.5461.2225

[26] Levitus, S., Antonov, J. and Boyer, T. (2005) Warming of the world ocean, 1955-2003. Geophysical Research Letters, 32, L02604. doi:10.1029/2004GL021592

[27] Aebischer, N.J., Coulson, J.C. and Colebrook, J.M. (1990) Parallel long-term trends across four marine trophic levels and weather. Nature, 347, 753-755. doi: $10.1038 / 347753 \mathrm{a} 0$

[28] Frederiksen, M., Edwards, M., Richardson, A.J., Halliday, N.C. and Wanless, S. (2006) From plankton to top predators: Bottom-up control of a marine food web across four trophic levels. Journal of Animal Ecology, 75, 1259-1268. doi:10.1111/j.1365-2656.2006.01148.x

[29] Grémillet, D. and Charmantier, A. (2010) Shifts in phenotypic plasticity constrain the value of seabirds as ecological indicators of marine ecosystems. Ecological Applications, 20, 1498-1503. doi:10.1890/09-1586.1

[30] Sydeman, W.J., Hester, M.M., Thayer, J.A., Gress, F., Martin, P. and Buffa, J. (2001) Climate change, repro- ducetive performance and diet composition of marine birds in the southern California Current System, 19691997. Progress in Oceanography, 49, 309-329. doi:10.1016/S0079-6611(01)00028-3

[31] Montevecchi, W.A. and Myers, R.A. (1997) Centurial and decadal oceanographic influences on changes in northern gannet populations and diets in the north-west Atlantic: implications for climate change. ICES Journal of Marine Science, 54, 608-614. doi:10.1006/jmsc.1997.0265

[32] Pauly, D., Watson, R. and Alder, J. (2005) Global trends in world fisheries: Impacts on marine ecosystems and food security. Philosophical Transactions of the Royal Society of London B, 360, 5-12. doi:10.1098/rstb.2004.1574

[33] Constable, A. J. and S. Doust. (2009) Southern Ocean Sentinel: An international program to assess climate change impacts on marine ecosystems. Report of an International Workshop, ACECRC (Antarctic Climate and Ecosystems Cooperative Research Centre), WWF-Australia, Hobart, Australia.

[34] Constable, A. J., de la Mare, W. K., Agnew, D. J., Everson, I. and Miller, D. (2000) Managing fisheries to conserve the Antarctic marine ecosystem: Practical implementation of the Convention on the Conservation of Antarctic Marine Living Resources (CCAMLR). ICES Journal of Marine Science, 57, 778-791. doi:10.1006/jmsc.2000.0725

[35] Furness, R.W. and Camphuysen, K. (1997) Seabirds as monitors of the marine environment. ICES Journal of Marine Science, 54, 726-737.

doi:10.1006/jmsc.1997.0243

[36] Mössner, S. and Ballschmiter, K. (1997) Marine mammals as global pollution indicators for organochlorines. Chemosphere, 34, 1285-1296. doi:10.1016/S0045-6535(97)00426-8

[37] Beckmen, K.B., Ylitalo, G.M., Towell, R.G., Krahn, M.M., O'Hara, T.M. and Blake, J.E. (1999) Factors affecting organochlorine contaminant concentrations in milk and blood of northern fur seal (Callorhinus ursinus) dams and pups from St. George Island, Alaska. The Science of the Total Environment, 231, 183-200. doi:10.1016/S0048-9697(99)00094-7

[38] Kurup, D.K.N. and Zacharias, V.J. (1994) Birds of Lakshadweep Islands. Forktail, 10, 49-64.

[39] Mathew, D.N., Gandhi, T., Santharam, V., Rajan, V.J. and Mathew, G. (1991) An ornithological expedition to the Lakshadweep archipelago: Assessment of threats to pelagic and other birds and recommendations. An ornithological study. Madras Naturalists' Society, Madras. http://www.indianbirds.in/pdfs/An\%20ornithological $\% 20$ expedition.pdf

[40] Feare, C.J. (1976) The exploitation of sooty tern eggs in the Seychelles. Biological Conservation, 10, 169-181. doi:10.1016/0006-3207(76)90033-1

[41] Mathew, D.N., Mathew, G. and Gandhi, T. (1996) Breeding seasons and conservation of the terns Sterna fuscata and Anous stolidus in the Lakshadweep. Journal of the Bombay Natural History Society, 93, 507-510. 
[42] Jones, H.P., Tershy, B.R., Zavaleta, E.S., Croll, D.A., Keitt, B.S., Finkelstein, M.E. and Howald, G.R. (2008) Severity of the effects of invasive rats on seabirds: A global review. Conservation Biology, 22, 16-26. doi:10.1111/j.1523-1739.2007.00859.x

[43] Pernetta, J.C. (1993) Marine protected area needs in the South Asian Seas Region. A Marine Conservation and Development Report, International Union for Conservation of Nature and Natural Resources, Gland.

[44] Feare, C.J. (1984) Seabird status and conservation in the tropical Indian Ocean. In: Croxall, J. P., Evans, P.G.H. and Schreiber, R.W., Eds., Status and Conservation of the World's Seabirds, International Council for Bird Preservation, Cambridge, 457-471.

[45] Rodgers, W.A. and Panwar, S.H. (1988) Biogeographical classification of India. New Forest, Dehra Dun, India.

[46] Mallory, M.L., Robinson, S.A., Hebert, C.E. and Forbes, M.R. (2010) Seabirds as indicators of aquatic ecosystem conditions: A case for gathering multiple proxies of seabird health. Marine Pollution Bulletin, 60, 7-12. doi:10.1016/j.marpolbul.2009.08.024

[47] Burger, J. and Gochfeld, M. (2004) Marine birds as sentinels of environmental pollution. EcoHealth, 1, 263-274. doi:10.1007/s10393-004-0096-4

[48] Cairns, D.K. (1987) Seabirds as indicators of marine food supplies. Biological Oceanography, 5, 261-271.

[49] Ramesh, A., Tanabe, S., Subramanian, A.N., Mohan, D., Venugopalan, V.K. and Tatsukawa, R. (1990) Persistent organochlorine residues in green mussels from coastal waters of South India. Marine Pollution Bulletin, 21, 587590. doi:10.1016/0025-326X(90)90608-B

[50] Burger, J. (2002) Food chain differences affect heavy metals in bird eggs in Barnegat Bay, New Jersey. Environmental Research, 90, 33-39. doi:10.1006/enrs.2002.4381

[51] Cipro, C.V.Z., Taniguchi, S. and Montone, R.C. (2010) Occurrence of organochlorine compounds in Euphausia superba and unhatched eggs of Pygoscelis genus penguins from Admiralty Bay (King George Island, Antarctica) and estimation of biomagnification factors. Chemosphere, 78, 767-771. doi:10.1016/j.chemosphere.2009.10.006

[52] Qasim, S.Z. and Sengupta, R. (1983) Marine pollution studies in India. In: Varshney, C.K., Ed., Water Pollution and Management Reviews, South Asian Publishers Pvt. Ltd., New Delhi, 139-159.

[53] Staffan, H. (1994) An environmental assessment of the Bay of Bengal Region. The Swedish Centre for Coastal Development and Management of Aquatic Resources (SWEDMAR), Final Report.

[54] Kaly, U.L. (2004) Review of land-based sources of pollution to the coastal and marine environments in the BOBLME Region. Bay of Bengal Large Marine Ecosystem (BOBLME) Theme Report, GCP/RAS/179/WBG.10 FAO-BOBLME Programme. http://www.boblme.org/documentRepository/Theme \%2 0Land $\% 20$ Based $\% 20$ Pollution $\% 20-\% 20 \% 20$ Urusla $\% 20$ $\underline{\text { Kaly.pdf }}$
[55] Sherman, K. (2003) Physical, biological, and human forcing of biomass yields in large marine ecosystems. International Council for the Exploration of the Sea Council Meeting. http://info.ices.dk/products/CMdocs/2003/P/P1203.PDF

[56] Heileman, S., Bianchi, G. and Funge-Smithm, S. (2007) LME34: Bay of Bengal. NOAA and Sea around Us Project (SAUP). http://www.lme.noaa.gov/lmeweb/LME Report/lme 34.p df

[57] Jaquemet, S., Le Corre, M., Marsac, F., Potier, M. and Weimerskirch, H. (2005) Foraging habitats of the seabird community of Europa Island (Mozambique Channel). Marine Biology, 147, 573-582.

[58] Jaquemet, S., Corre, M.L. and Weimerskirch, H. (2004) Seabird community structure in a coastal tropical environment: Importance of natural factors and fish aggrgating devices (FADs). Marine Ecology Progress Series, 268, 281-292.

http://www.int-res.com/articles/meps2004/268/m268p281 .pdf

[59] Barrett, R.T., Camphuysen, C.J., Anker-Nilssen, T., Chardine, J.W., Furness, R.W., Garthe, S., Huppop, O., Leopold, M.F., Montevecchi, W.A. and Veit, R.R. (2007) Diet studies of seabirds: A review and recommendations. Journal of Marine Science, 64, 1675-1691. doi:10.1093/icesjms/fsm152

[60] Abdulali, H. (1964) The birds of Andaman and Nicobar islands. Journal of Bombay Natural History Society, 61, 483-571.

[61] Abdulali, H. (1942) The distribution of the rosy tern. Journal of Bombay Natural History Society, 43, 104.

[62] Blyth E. (1846) Notes on the fauna of the Nicobar Islands-Reptilia. Journal of Bombay Natural History Society, 15, 367-379.

[63] Abdulali, H. (1967b) The birds of Nicobar islands. Journal of Bombay Natural History Society, 64, 139-190.

[64] Baker, E.C.S. (1922-1930) Fauna of British India, Birds (1-8), Taylor \& Francis, London.

[65] Ripley II, S.D. (1961) A synopsis of the birds of India and Pakistan. Bombay Natural History Society, Mumbai.

[66] Abdulali, H. (1978) The birds of great and car Nicobar islands with some notes on wildlife conservation in the islands. Journal of Bombay Natural History Society, 75, 744-772.

[67] Balachandran, S. (1995) Shorebirds of the marine national park in the Gulf of Mannar, Tamil Nadu. Journal of the Bombay Natural History Society, 92, 303-313.

[68] Balachandran, S., Rahmani, A.R. and Sathiyaselvam, P. (2005). Habitat evaluation of Chilka Lake with special reference to birds as bioindicators. Final Report (20012005), Bombay Natural History Society, Mumbai.

[69] Li, Z.W.D., Bloem, A., Delany S., Martakis G. and Quintero, J.O. (2009) Status of Waterbirds in Asia-Results of the Asian Waterbird Census: 1987-2007. Wetlands International, Kuala Lumpur.

[70] Stanford, J.K. (1937) On the breeding of the Oyster- 
catcher (Haematopus ostralegus sub sp.) and other birds in the Bengal Sunderbans. Journal of Bombay Natural History Society, 39, 867-868.

[71] Sivakumar, K. and Sankaran, R. (2002) New records of birds from the Andaman and Nicobar Islands. Forktail, 18, 149-150.

[72] Aldridge, J. (1998) Skua at Fisherman's cove. Blackbuck, 14, 1-4.
[73] Yahya, H.S.A and Ahmad, A. (2002) White tern, Gygis alba sighted at Narcondam Island, Bay of Bengal, India. Forktail, 18, 148.

[74] Raju, K.S.R. and Sekhar, P.B. (1971) Some interesting bird record from Point Calimere. Journal of Bombay Natural History Society, 68, 457-459.

[75] Ministry of Agriculture, Government of India (2008) Handbook on fisheries statistics. 


\section{APPENDIX A}

Table 1. Breeding species.

\begin{tabular}{|c|c|c|c|c|c|c|}
\hline Species Name & Sites & Subsites & $\begin{array}{c}\text { IUCN } \\
\text { conservation status }\end{array}$ & $\begin{array}{l}\text { Population } \\
\text { estimate }\end{array}$ & References & Remarks \\
\hline $\begin{array}{c}\text { Roseate Tern } \\
\text { (Sterna dougallii) }\end{array}$ & $\begin{array}{l}\text { Andaman and } \\
\text { Nicobar } \\
\text { islands }\end{array}$ & North Button island & $\begin{array}{c}\text { Least } \\
\text { concern (LC) }\end{array}$ & $\begin{array}{c}\text { Not } \\
\text { available }\end{array}$ & {$[60]$} & $\begin{array}{c}\text { Known to be breeding in } \\
\text { Port Blair, as noted by } \\
\text { Butler }\end{array}$ \\
\hline $\begin{array}{c}\text { Roseate Tern } \\
\text { (Sterna dougallii) }\end{array}$ & $\begin{array}{l}\text { Gulf of } \\
\text { Mannar }\end{array}$ & $\begin{array}{l}\text { Rameshwaram } \\
\text { island }\end{array}$ & $\begin{array}{c}\text { Least } \\
\text { concern (LC) }\end{array}$ & $\begin{array}{c}\text { Not } \\
\text { available }\end{array}$ & {$[61]$} & Museum specimen \\
\hline $\begin{array}{l}\text { Black-naped Tern } \\
\text { (Sterna sumatrana) }\end{array}$ & $\begin{array}{l}\text { Andaman and } \\
\text { Nicobar } \\
\text { islands }\end{array}$ & $\begin{array}{l}\text { Between the North } \\
\text { Sentinel and west } \\
\text { coast of South } \\
\text { Andamans }\end{array}$ & $\begin{array}{c}\text { Least } \\
\text { concern (LC) }\end{array}$ & $\begin{array}{c}\text { Not } \\
\text { available }\end{array}$ & {$[60]$} & $\begin{array}{l}200 \text { individuals } \\
\text { sighted at sea. }\end{array}$ \\
\hline $\begin{array}{l}\text { Black-naped Tern } \\
\text { (Sterna sumatrana) }\end{array}$ & $\begin{array}{l}\text { Andaman and } \\
\text { Nicobar } \\
\text { islands }\end{array}$ & $\begin{array}{l}\text { Port Blair Little } \\
\text { islets } \\
\text { on the east coast }\end{array}$ & $\begin{array}{c}\text { Least } \\
\text { concern (LC) }\end{array}$ & $\begin{array}{c}\text { Not } \\
\text { available }\end{array}$ & {$[62]$} & breeding record \\
\hline $\begin{array}{l}\text { Black-naped Tern } \\
\text { (Sterna sumatrana) }\end{array}$ & $\begin{array}{l}\text { Andaman and } \\
\text { Nicobar islands }\end{array}$ & - & Least concern (LC) & $\begin{array}{c}\text { Not } \\
\text { available }\end{array}$ & {$[63]$} & $\begin{array}{c}\text { Known to breed } \\
\text { abundantly in the } \\
\text { Nicobars [62]. In Andamans, } \\
\text { found to be breeding on } \\
\text { snake island and other } \\
\text { islands in } \\
\text { company with Rosy Terns. }\end{array}$ \\
\hline $\begin{array}{c}\text { Bridled tern } \\
\text { (Onychoprion anaethetus) } \\
\text { formerly known as } \\
\text { (Sterna anaethetus) }\end{array}$ & $\begin{array}{l}\text { Andaman and } \\
\text { Nicobar } \\
\text { islands }\end{array}$ & $\begin{array}{l}\text { Ross island, South } \\
\text { Andamans }\end{array}$ & Least concern (LC) & $\begin{array}{c}\text { Not } \\
\text { available }\end{array}$ & {$[60]$} & $\begin{array}{l}\text { Straggler to the } \\
\text { Andamans during } \\
\text { winter. Known to be } \\
\text { breeding in the islands of } \\
\text { Adam's bridge between } \\
\text { India and Srilanka. }\end{array}$ \\
\hline $\begin{array}{c}\text { Lesser crested Tern } \\
\text { (Thalasseus bengalensis) }\end{array}$ & $\begin{array}{l}\text { Andaman and } \\
\text { Nicobar } \\
\text { islands }\end{array}$ & $\begin{array}{c}\text { North Button island } \\
\text { and North coast of } \\
\text { Camorta }\end{array}$ & Least concern (LC) & $\begin{array}{c}\text { Not } \\
\text { available }\end{array}$ & {$[60]$} & $\begin{array}{l}\text { Known to breed in the } \\
\text { Rameshwaram island and } \\
\text { Lakshadweep but no } \\
\text { evidence yet. }\end{array}$ \\
\hline $\begin{array}{l}\text { Brown Noddy } \\
\text { (Anous stolidus) }\end{array}$ & $\begin{array}{l}\text { Andaman and } \\
\text { Nicobar } \\
\text { islands }\end{array}$ & - & Least concern (LC) & $\begin{array}{c}\text { Not } \\
\text { available }\end{array}$ & {$[60]$} & $\begin{array}{l}\text { Confirmed breeding } \\
\text { records for Lakshadweep } \\
\text { islands. Also known to breed } \\
\text { in the small islets of } \\
\text { Nicobar [65]. }\end{array}$ \\
\hline $\begin{array}{l}\text { Brown Noddy } \\
\text { (Anous stolidus) }\end{array}$ & $\begin{array}{l}\text { Andaman and } \\
\text { Nicobar } \\
\text { islands }\end{array}$ & - & Least concern (LC) & $\begin{array}{c}\text { Not } \\
\text { available }\end{array}$ & {$[63,66]$} & $\begin{array}{l}\text { Nests in the small islets of } \\
\text { Nicobars [65]. }\end{array}$ \\
\hline $\begin{array}{c}\text { Little Tern } \\
\text { (Sterna albifrons) }\end{array}$ & $\begin{array}{l}\text { Gulf of } \\
\text { Mannar }\end{array}$ & & Least concern (LC) & $\begin{array}{c}\text { Not } \\
\text { available }\end{array}$ & {$[67]$} & $\begin{array}{l}\text { Common breeding } \\
\text { resident in the area. }\end{array}$ \\
\hline $\begin{array}{c}\text { Little Tern } \\
\text { (Sterna albifrons) }\end{array}$ & Chilka Lake & Nalabana island & Least concern (LC) & & {$[68]$} & \\
\hline $\begin{array}{c}\text { Little Tern } \\
\text { (Sterna albifrons) }\end{array}$ & $\begin{array}{l}\text { Chilika Lake } \\
\text { (Combined) }\end{array}$ & & Least concern (LC) & 6720 & {$[69]$} & \\
\hline
\end{tabular}




\section{Continued}

\begin{tabular}{|c|c|c|c|c|c|c|}
\hline $\begin{array}{c}\text { Gull-billed Tern } \\
\text { (Gelochelidon nilotica) }\end{array}$ & $\begin{array}{l}\text { Andaman and } \\
\text { Nicobar islands }\end{array}$ & $\begin{array}{c}\text { South } \\
\text { Andamans }\end{array}$ & $\begin{array}{l}\text { Least concern } \\
\text { (LC) }\end{array}$ & $\begin{array}{c}\text { Not } \\
\text { available }\end{array}$ & {$[60]$} & $\begin{array}{l}\text { The single record of the } \\
\text { species from Andaman and } \\
\text { Nicobar islands. }\end{array}$ \\
\hline $\begin{array}{c}\text { Gull-billed Tern } \\
\text { (Gelochelidon nilotica) }\end{array}$ & Chilka Lake & Nalabana island & $\begin{array}{l}\text { Least concern } \\
\text { (LC) }\end{array}$ & Not available & {$[68]$} & \\
\hline $\begin{array}{c}\text { Gull-billed Tern } \\
\text { (Gelochelidon nilotica) }\end{array}$ & hilka Lake Combined & - & $\begin{array}{l}\text { Least concern } \\
\text { (LC) }\end{array}$ & 11995 & [69] & \\
\hline $\begin{array}{c}\text { Gull-billed Tern } \\
\text { (Gelochelidon nilotica) }\end{array}$ & $\begin{array}{c}\text { Kolleru } \\
\text { (Gudivaka \& Penu- } \\
\text { maka Lanka,Godavari } \\
\text { R, Pedayedladadi) }\end{array}$ & - & $\begin{array}{l}\text { Least concern } \\
\text { (LC) }\end{array}$ & 8365 & [69] & \\
\hline $\begin{array}{c}\text { Gull-billed Tern } \\
\text { (Gelochelidon nilotica) }\end{array}$ & Sunderbans & $\begin{array}{l}100 \text { miles } \\
\text { south of Khulna }\end{array}$ & $\begin{array}{l}\text { Least concern } \\
\text { (LC) }\end{array}$ & Not available & {$[70]$} & $\begin{array}{l}\text { A large breeding colony was } \\
\text { sighted. }\end{array}$ \\
\hline $\begin{array}{l}\text { Large crested Tern } \\
\text { (Thalasseus bergii) }\end{array}$ & $\begin{array}{l}\text { Adam's Bridge } \\
\text { Islands,Srilanka }\end{array}$ & & No Information & 13677 & [69] & \\
\hline $\begin{array}{l}\text { Large crested Tern } \\
\text { (Thalasseus bergii) }\end{array}$ & Sunderbans & $\begin{array}{l}100 \text { miles } \\
\text { south of Khulna }\end{array}$ & No information & $60-80$ & {$[70]$} & $\begin{array}{c}\text { Their nests are almost close } \\
\text { to each other. A single egg } \\
\text { laid in a bare hollow in the } \\
\text { sand. }\end{array}$ \\
\hline $\begin{array}{c}\text { Whiskered Tern } \\
\text { (Chlidonias hybridus) }\end{array}$ & $\begin{array}{l}\text { Chilka Lake } \\
\text { Combined }\end{array}$ & - & Least concern & 15742 & [69] & \\
\hline $\begin{array}{c}\text { Whiskered Tern } \\
\text { (Chlidonias hybridus) }\end{array}$ & Ousteri Tank & - & Least concern & 1840 & [69] & \\
\hline $\begin{array}{c}\text { Whiskered Tern } \\
\text { (Chlidonias hybridus) }\end{array}$ & $\begin{array}{l}\text { Karavetti-Vettakudi } \\
\text { Sanctuary }\end{array}$ & - & Least concern & 1200 & [69] & \\
\hline $\begin{array}{l}\text { Whiskered Tern } \\
\text { (Chlidonias hybridus) }\end{array}$ & $\begin{array}{l}\text { Thenpakkam } \\
\text { Backwaters }\end{array}$ & - & Least concern & 3500 & [69] & \\
\hline
\end{tabular}

Table 2. Non-breeding species.

\begin{tabular}{|c|c|c|c|c|c|c|}
\hline Species Name & Sites & Subsites & $\begin{array}{c}\text { IUCN } \\
\text { conservation status }\end{array}$ & $\begin{array}{l}\text { Population } \\
\text { estimates }\end{array}$ & References & Remarks \\
\hline $\begin{array}{c}\text { (Fregetta tropica) } \\
\text { Dusky vented Storm Petrel }\end{array}$ & $\begin{array}{l}\text { Andaman and Nicobar } \\
\text { islands }\end{array}$ & - & $\begin{array}{c}\text { LC } \\
\text { (Least concern) }\end{array}$ & Not available & {$[60]$} & Doubtful record. \\
\hline $\begin{array}{c}\text { (Fregetta tropica) } \\
\text { Dusky vented Storm Petrel }\end{array}$ & $\begin{array}{l}\text { Andaman and Nicobar } \\
\text { islands }\end{array}$ & $\begin{array}{c}\text { Battye Malve, South } \\
\text { of Car } \\
\text { Nicobar. }\end{array}$ & $\begin{array}{c}\text { LC } \\
\text { (Least concern) }\end{array}$ & Not available & {$[66]$} & $\begin{array}{l}\text { A single doubtful } \\
\text { record of the species sighted } \\
\text { on April 12, } 1977 .\end{array}$ \\
\hline $\begin{array}{l}\text { (Oceanites ocenaicus) } \\
\text { Wilson's Storm Petrel }\end{array}$ & $\begin{array}{l}\text { Andaman and Nicobar } \\
\text { islands }\end{array}$ & $\begin{array}{l}\text { Between Preparis } \\
\text { and coco. }\end{array}$ & $\begin{array}{c}\text { LC } \\
\text { (Least concern) }\end{array}$ & Not available & {$[60]$} & $\begin{array}{l}\text { Recorded by Biswas form } \\
\text { Andamans in 1964. Not a } \\
\text { definite record. }\end{array}$ \\
\hline $\begin{array}{l}\text { Long-tailed Tropic bird } \\
\text { (Phaethon leptutus) }\end{array}$ & $\begin{array}{l}\text { Andaman and Nicobar } \\
\text { islands }\end{array}$ & Andamans & $\begin{array}{c}\text { LC } \\
\text { (Least concern) }\end{array}$ & Not available & {$[60]$} & {$[62]$.} \\
\hline $\begin{array}{l}\text { Red-tailed Tropic bird } \\
\text { (Phaethon rubricada) }\end{array}$ & $\begin{array}{l}\text { Andaman and Nicobar } \\
\text { islands }\end{array}$ & Nicobars & $\begin{array}{c}\text { LC } \\
\text { (Least concern) }\end{array}$ & Not available & {$[60,63]$} & $\begin{array}{l}\text { Only one record from the } \\
\text { subcontinent [62]. Has to } \\
\text { reconfirmed. }\end{array}$ \\
\hline $\begin{array}{l}\text { Red-billed Tropicbird } \\
\text { (Phaethon aetherens) }\end{array}$ & $\begin{array}{c}\text { Andaman and Nicobar } \\
\text { islands }\end{array}$ & $\begin{array}{l}\text { Cocos and Treis } \\
\text { (Nicobars) }\end{array}$ & $\begin{array}{c}\text { LC } \\
\text { (Least concern) }\end{array}$ & Not available & {$[60,63]$} & No confirmed records [65]. \\
\hline
\end{tabular}




\section{Continued}

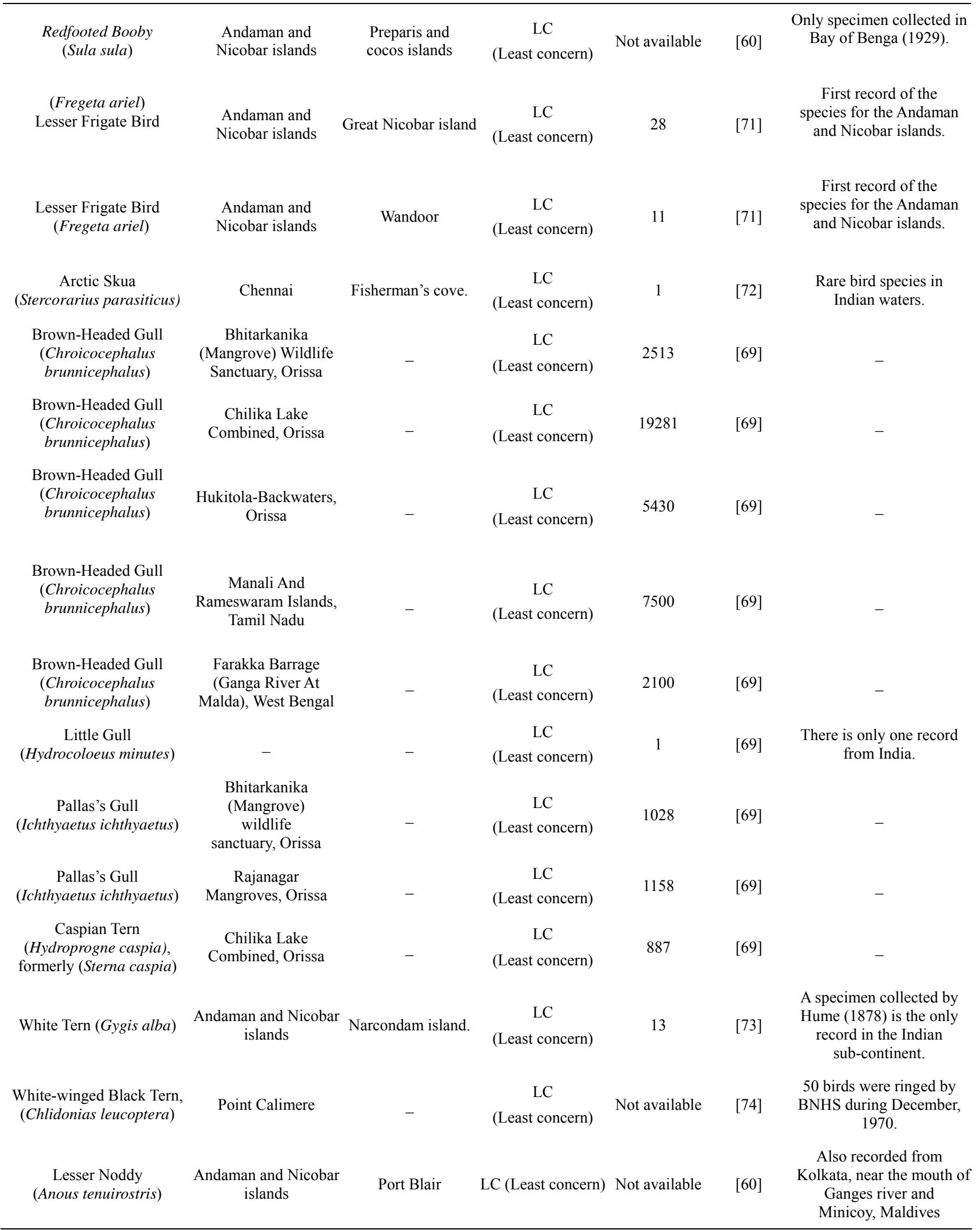




\section{APPENDIX B}

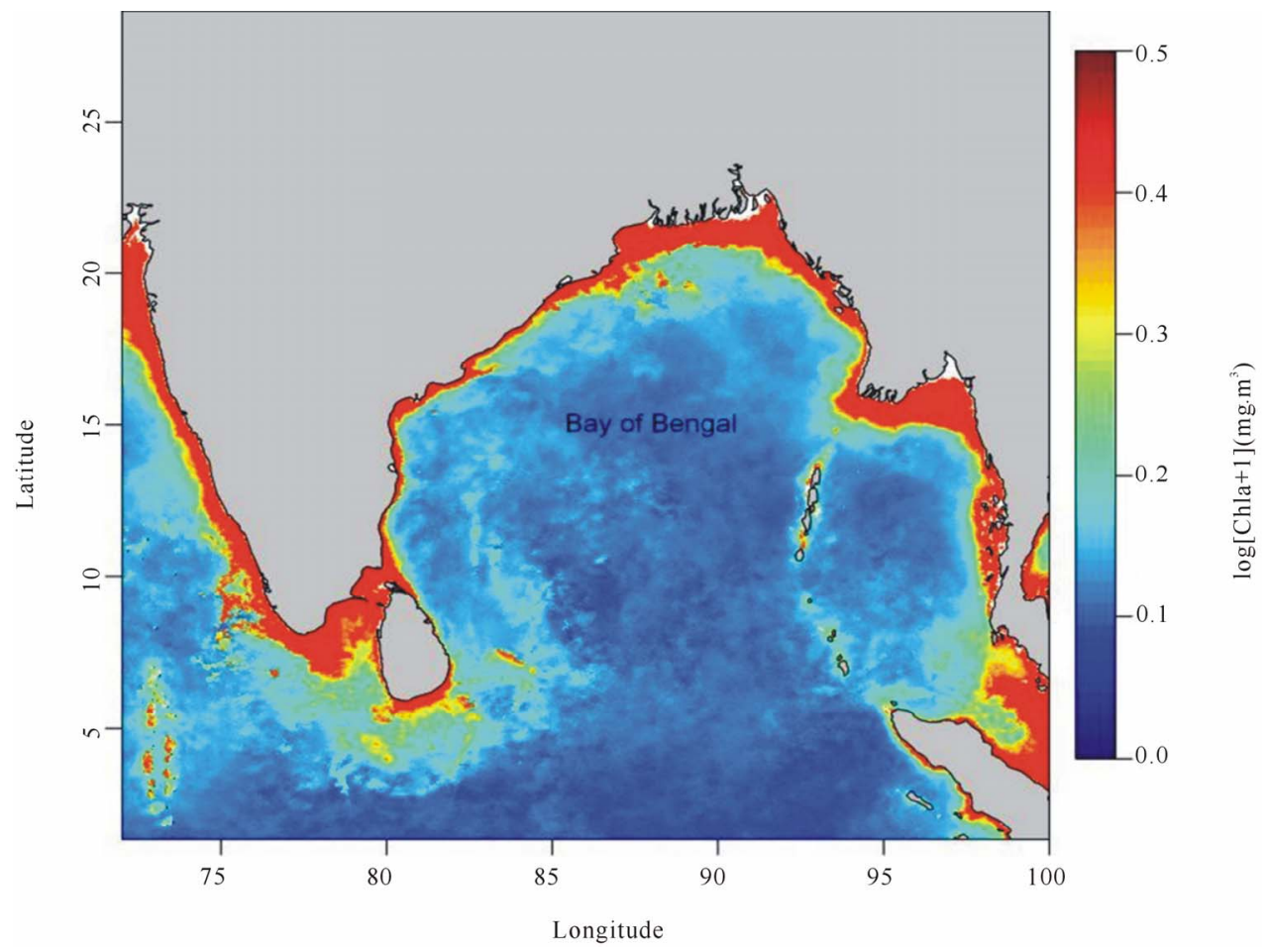

Figure 1. Mean Monthly Chlorophyll-a concentration (CHLA) in Bay Of Bengal (BOB) (January to December, 2011). Note the productivity is very low in the open seas than the coastal waters, which receive perennial runoff from the rivers, especially in the northern part of Bay of Bengal (BOB). (Source: Derived from the monthly Chlorophyll-a data downloaded from coast watch browser, NASA).

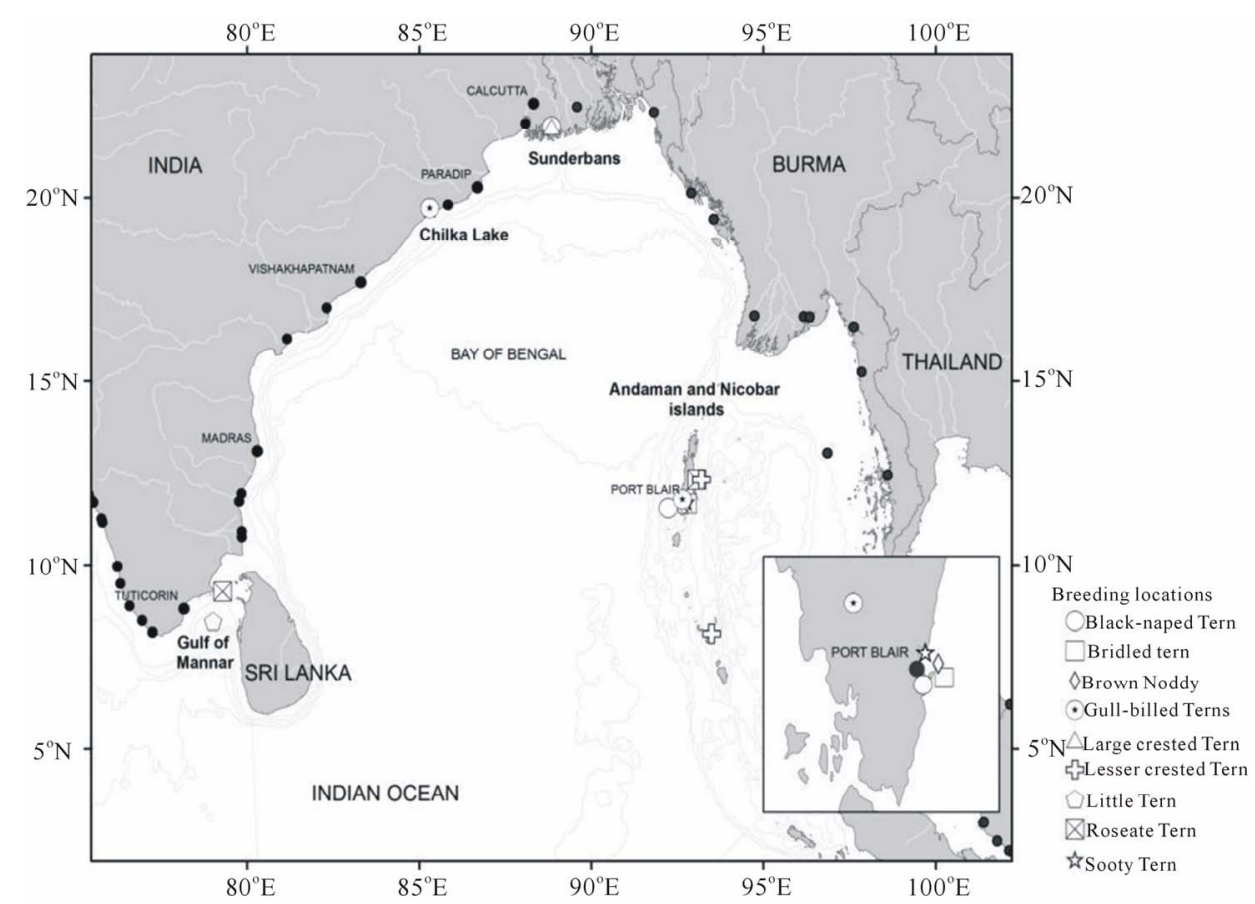

Figure 2. Localities of the breeding seabird population in the BOBLME. Among them the Black-naped Tern is the only resident species in the Indian part of BOBLME. The black dots indicate major and minor ports along the coastline of the Bay of Bengal. (Source: Table 1.). 


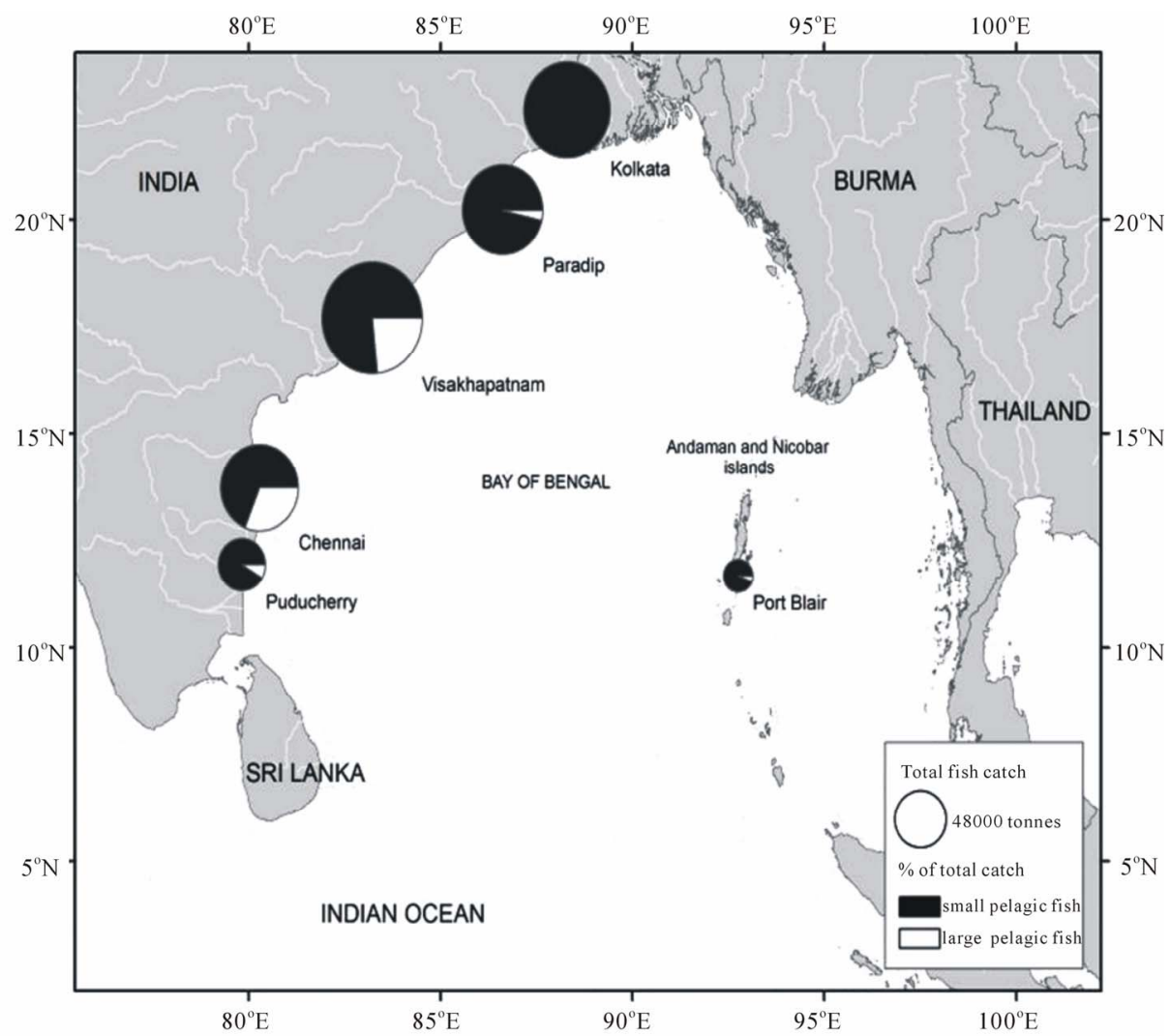

Figure 3. The size of the circles represents the percentage of pelagic fish catch comprising small pelagic like Sardines, Anchovies, Herrings and the large pelagic like Tunas, in each of the six major and minor port cities and towns along the East coast of India. Source: [75]. 